\title{
Entrepreneurial Orientation Model in Cluster Development of Potato Agribusiness
}

\author{
Lukman Hakim* \\ Fakultas Pertanian \\ Universitas Syiah Kuala \\ Banda Aceh, Indonesia \\ lukman.hakim.sp.mp@gmail.com
}

\author{
Tomy Perdana, Maman Haeruman K, Yosini Deliana \\ Fakultas Pertanian \\ Universitas Padjadjaran \\ Bandung, Indonesia \\ Tomyp1973@yahoo.com
}

\begin{abstract}
The objectives of this study is to design a model of entrepreneurship in the cluster development of potato agribusiness as an effort to increase revenue and bargaining position of farmers in Aceh Province. System dynamics methodology was applied to achieve these objectives. The study was carried out in Aceh Tengah and Bener Meriah Districts as potato production center in Aceh Province. Identification required for cluster models had been conducted through study of literature and interviews with experts from stakeholders including practitioners and the policy makers involved in providing input supply, cultivation, and marketing of potato output. Data collected consisted of primary and secondary data. The primary data were obtained through observation, discussion, and in-depth interview with respondents, While secondary data had been obtained from the study of literature from various sources of literature, books, scientific journals, and a variety of publications related to this study. Formulation of the models was conducted by using Vensim DSS software, followed by simulation. The results of this study showed that the higher the market opportunities and farmer returns, the higher the motivation of new entrepreneurs in investing, and after adding a number of farmer's competent scenarios, showed an increase in production of potato farmers.
\end{abstract}

Keywords-system dynamics; entrepreneurial orientation; agribusiness cluster; potato cultivation

\section{INTRODUCTION}

Food has a promising business prospect over time and is a sustainable business in the future. The issue of food is one of the national problems. Food supplies are very relevant to the welfare and survival issues of the nation of Indonesia. The Government aware that in order to face the challenges of the global market, the pattern of subsistence agriculture has to be changed into advanced business-oriented agriculture, that requires high efficiency, market-oriented to quality and competitive prices in sufficient quantity, timely continuity of supply for the domestic market and international market.

Indonesia is an agricultural country that has diverse natural resources and potential for development, and horticulture is one of the strategic agricultural sub-sector. This sub-sector has a high economic value, so that the horticulture agribusiness is reliable as a source of income of farmers from small scale to large. Horticulture has advantages over other sub-sector, such as high value, diversity and potential of the domestic and world market uptake continues to increase. However, this potential cannot be utilized optimally for agro-horticulture are still facing some problems. Factors that hinder its development, such as low productivity, dispersed locations, narrow business scale and inefficient, as well as the lack of support policies and regulations in the areas of banking, transport and trade. The condition causes the competitiveness of the national horticultural commodities relatively less when compared with other countries [1].

One of horticultural commodities is potato (Solanum tuberosum L.). Based on the basic pattern of regional development in 2014, several commodities have been established as the leading commodity areas, one of which is potato. Potato production centers located in the Aceh Province are Aceh Tengah and Bener Meriah. Both regions cultivate Granola potato in the land area development of 79.217 hectares. As many as 3,228 hectares (4 percent) of area has been planted with vegetables and only (1,500 hectares) of area is planted with potato [2]. Figure 1 shows the development of the harvested area and production of potato in the Province of Aceh period 2005-2014.

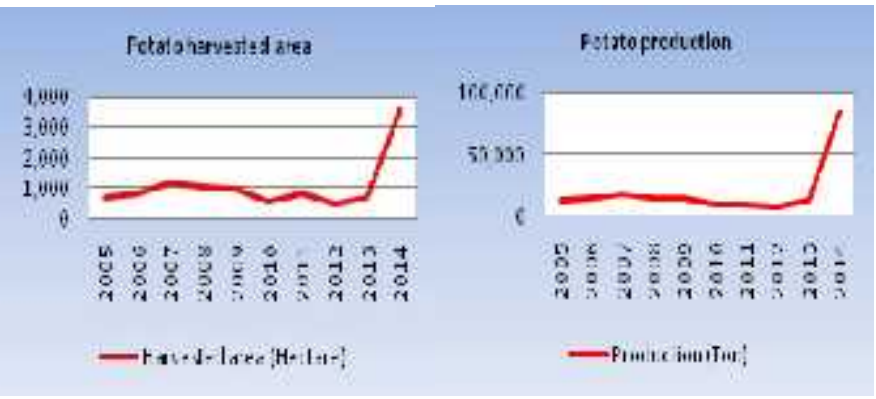

Fig. 1. Development and production of potato harvested area in Aceh Province, period 2005-2014 [3]

Figure 1 shows the increase in harvested area and volume of potato production in 2005 to 2007 , followed by a slowdown 
of the years 2008 to 2012 . The decline was triggered by the lack of availability of certified seed potato, in addition to the high prices of these seeds, causing the majority of farmers switch on seed that is not certified with a more affordable price. As a result, the productivity of potato in Aceh declined. Subsequently, the harvested area and production of potato began to rise in 2013 and is very significant in 2014, with an area of 3,560 hectares and harvested potato production reached 83.888 tons. It is highly driven by the improved atmosphere potato cultivation in Aceh, marked by the local government support in the form of cooperation with the Ministry of Agriculture of Malaysia, making potato products for export. This condition motivates farmers and businesses in the development of new production of potato cultivation base in Aceh.

The cluster development of potato agribusiness in Aceh is seen to provide an alternative strategy to improve the quality, value-added, and competitiveness of commodity. Potato Agribusiness is a complex and dynamic system, then in the process of model development, we need a method of system dynamics approach that could serve as a basis for decisionmaking and policy within the cluster development that is expected to increase farmer's incomes and bargaining position.

Based on the literature search results in the form of books, journals, and scientific articles, it is known that specific research model of entrepreneurial orientation on potato agribusiness cluster development in Aceh province has so far not been reported. Research related to potato commodity that has been reported are limited to the research model of the development of potato agribusiness in Nanggroe Aceh Darussalam through linkages products and actors [4], modeling of economic and agro-environmental dynamics of potato production systems [5], and application simulation models for the prediction of climate change impacts on the productivity of potato (Solanum tuberosum L.) in Indonesia [6].

Research related to entrepreneurship in agribusiness cluster development, particularly in the potato commodity, is still minimal. Most of the research done on the cluster of nonagricultural industries, such as oil and gas industry [7], furniture industry [8], entrepreneurship and innovation clusters [9]. Clusters research associated with agriculture has only been done on perpetrators of the fish processing industry [10], agroindustry of essential oils [11], agro-industry of aren [12], industrial cluster of cane sugar [13], cluster of hot pepper [14], cluster of engineering agro-food development [15], managing the risks involved in agribusiness clusters of red chili [16], and downstream industries cluster of oil palm [17].

Based on the study conducted during the research, reinforced by theory and results of previous research, the authors summarize that one of the major factors in the success of the cluster development of potato agribusiness in Aceh Province is determined by the orientation of entrepreneurship (entrepreneurial orientation-EO) businesses in the cluster.

The goals of this research are: (a) to know and understand the effects of entrepreneurial orientation in the cluster development of potato agribusiness in Aceh Province, (b) to know and understand the structure of the entrepreneurial orientation forming in the cluster development of potato agribusiness in Aceh Province, (c) to design model of entrepreneurial orientation in the cluster development of potato agribusiness that is expected to increase revenue and bargaining position of farmers in the Province of Aceh.

\section{ENTREPRENEURIAL ORIENTATION AS A STRATEGY TO INCREASE INNOVATION}

Entrepreneur is often defined by the businessmen, trader, merchant, or by the term self-employed. The word "entrepreneur" is derived from the French "entre prendre", means someone who is trying to organize, manage, and bear the risk of a business [18]. An entrepreneur is someone who bears the risk of buying and selling [19]. Entrepreneurs are people who buy material for a certain price to sell again at a more favorable price [20].

According to Schumpeter [21], an entrepreneur seeks to reform production patterns by applying a new discovery, or generally, a possible technical untried, to produce a new commodity, or to produce an old commodity in a new way. It is implemented through the use of a new source of supply of materials or a new marketing channel for the products produced. Entrepreneurship essentially consists of a series of actions that are not normally done in terms of implementing measures with routine business.

Ronstad [22], says that entrepreneurship is a dynamic process, that is, those that create incremental wealth. Such property is created by individuals who bear the main risk in the form of capital, time, and/or career commitments risk in terms of providing value for a particular product or service. Products or services, new or may be old or not be unique, but the value must be created by the entrepreneur through efforts to achieve and allocate all the skills and resources needed.

The essence of entrepreneurship is a new breakthrough. The company is said to have entrepreneurial if able to make new breakthroughs, both in the form of a market breakthrough with a new product/service, or product/service similar to the previous but in other market segments [23].

Birkinshaw [24], puts forward four ideas related to the understanding of entrepreneurship, namely:

- Corporate venturing. This concept assumes that in order to survive, new breakthrough made by a company should be separated from the main business. Therefore, this concept emphasizes the design of organization needed to carry out the activities relating to new breakthroughs that will be implemented, and how to harmonize with the parent company.

- Intrapreneurship. This approach is focused more on the individual employee who is deemed to have a tendency to act as an entrepreneur. The basic assumption of this approach is that all the big companies have a structure and system that can accommodate a variety of initiatives that encourage individuals to actively take advantage of the system. Thus, the concept of intrapreneurship emphasizes on how to dig the creativity of employees to answer the challenges that exist in the market. 
- Entrepreneurial transformation. This concept is developed based on the assumption that large companies have the ability to adapt with various changes around him. The big effect of the adaptation process to the corporate entrepreneurship depends on how companies perform alignment between the corporate culture and the prevailing system in the organization, so as to encourage people to work proactively, innovative, and take risks.

- Bringing the market inside. This concept is also true at the corporate level and focus more on structural changes that can be made to lead to entrepreneurial behavior. The use of the term the market as a metaphor is to describe the management and allocation of resources as well as human resource management system that uses the mindset as if there is competition in it (just like in the market). Management of internal management with techniques commonly used in the competitive market would encourage competition within the company that will lead to new breakthroughs.

As mentioned above, the essence of entrepreneurship is a new breakthrough, inroads into new markets, or already established with the new product/service, or existing launch new businesses by starting, or as a corporate business, which forms new entry. An overview of how a new breakthrough (new entry) was made, is called the entrepreneurial orientation, addressed by a process, practices and decision-making activities which resulted in a new breakthrough [23].

Lumpkin and Dess [23], defines proactiveness as a willingness to introduce something new through a process of trial and creativity aimed at developing a new product/service or a new process. Meanwhile, according to Webster's Ninth New Collegiate Dictionary [25], proactiveness is the action in anticipating the problems, needs, or changes that will occur in the future.

Miller [26], argues that to determine the orientation of entrepreneurship within a company can be seen in three dimensions, namely proactiveness, innovativeness, and the courage to take risks. Miller's approach became the basis of the study by other researchers, for example Covin and Slevin [27], conducted a study of the company's performance in environments with the level of competition as well as a friendlier. In that study, entrepreneurial orientation in a company is measured by the level of proactive, innovative, and making decisions based on the risk factors of each company.

Innovativeness is defined as a basic desire to move from technological or operational processes that exist in the present conditions [28]. Innovation is a step that must be done so that the company can survive and excel in competition in the era of globalization, where changes happen very quickly. Companies will no longer be able to survive with the same strategy for a long period of time.

Risk-taking is an intense effort to outperform the industry rivals. It is characterized by a combative or aggressive response posture aimed at improving position or overcoming a threat in a competitive market place. From this definition, it appears an element of uncertainty that makes a careful diagnostic process is required, so that the decision to produce or modify processes as a result of innovation will actually increase the value of the company [23].

\section{RESEARCH METHODOLOGY}

The method applied in this study is the methodology of system dynamics; a modeling approach based on systemic thinking and uses perspective based on the feedback information and delays, to understand the dynamics of complex behavior of a physical, biological, and social systems, which occurred on cluster of potato agribusiness. Aceh Tengah and Bener Meriah, as the potato production centers in Aceh Province, were chosen to be the working area of the study.

Identification of the need for cluster model done through literature and interviews with experts from stakeholders, namely practitioners and policy makers involved in the procedure of input supply, production, and marketing of potato output. Data collected consisted of primary and secondary data. The primary data obtained through observation, discussion and in-depth interviews with respondents, while secondary data obtained through the study of literature from various sources of literature, books, scientific journals, and a variety of publications related to this research. Formulation of model made by software Veneta Simulation (Vensim DSS), followed by simulation.

Data used in this study is numerical data, written data, and mental models [29]. On the numeric data type, the data used are parameters on the physical structure and decisions in cluster development of potato agribusiness studied, namely land, productivity, production, harvest, processing, supply of raw materials, market demand, and more. Written data is the resume of various references and literature used, such as secondary data, research journals, and books that are relevant to this study. Mental models are the rules that underlie decision making by the actors in the cluster development of potato agribusiness that are examined [30]. Data numeric and mental models are obtained from interviews with respondents, as well as a focus group discussion with multistakeholder involved in cluster development of potato agribusiness.

Determination of key informant is done through the integrated mapping of upstream and downstream on the activity of potato agribusiness. Key informant chosen are the whole stakeholders (stakeholder engagement) involved, ranging from actors, producers, supply chain, practitioners, and policy makers involved in the procedure of input supply, cultivation, and marketing of potato output. The next key informant is the decision makers at every actor in potato agribusiness, which consists of: raw material suppliers, farmers potato farming actors, marketers, and industrialists. The determination of key informant on the activities of potato agribusiness is undertaken purposively. The characteristics of informants can be seen in Table I. 
TABLE I. CHARACTERISTICS OF RESPONDENTS IN RESEARCH

\begin{tabular}{|c|c|c|c|}
\hline No & Actors & Position & $\begin{array}{c}\text { Number of } \\
\text { Respondents }\end{array}$ \\
\hline 1 & Potato Farmers & $\begin{array}{l}\text { Chairman and } \\
\text { Members }\end{array}$ & 20 \\
\hline 2 & Broker & Suppliers & 5 \\
\hline 3 & merchants District & Suppliers & 5 \\
\hline 4 & Traders Inter-City & Suppliers & 5 \\
\hline 5 & Retailer & Suppliers & 5 \\
\hline 6 & Cooperative management & $\begin{array}{l}\text { Chairman and } \\
\text { Members }\end{array}$ & 3 \\
\hline 7 & Rustic Potato Industry & Leaders and Members & 3 \\
\hline 8 & Microfinance Institutions & Leaders and Staff & 3 \\
\hline 9 & Bank of Aceh & $\begin{array}{l}\text { Leaders and Head of } \\
\text { subsection }\end{array}$ & 4 \\
\hline 10 & NGOs & Leaders and Members & 3 \\
\hline 11 & $\begin{array}{l}\text { Agricultural Extension } \\
\text { Centres }\end{array}$ & $\begin{array}{l}\text { Head of subsection } \\
\text { and mentor }\end{array}$ & 8 \\
\hline 12 & $\begin{array}{l}\text { Department of Agriculture } \\
\text { and Horticulture }\end{array}$ & $\begin{array}{l}\text { Head of subsection } \\
\text { and expert staff }\end{array}$ & 4 \\
\hline 13 & $\begin{array}{l}\text { Department of Industry } \\
\text { and Commerce }\end{array}$ & $\begin{array}{l}\text { Head of subsection } \\
\text { and expert staff }\end{array}$ & 4 \\
\hline 14 & $\begin{array}{l}\text { Central Bureau of } \\
\text { Statistics }\end{array}$ & $\begin{array}{l}\text { Head of subsection } \\
\text { and expert staff }\end{array}$ & 4 \\
\hline 15 & $\begin{array}{l}\text { Regional Development } \\
\text { Planning Agency }\end{array}$ & $\begin{array}{l}\text { Head of subsection } \\
\text { and expert staff }\end{array}$ & 4 \\
\hline 16 & Village office & $\begin{array}{l}\text { The village head and } \\
\text { village secretary }\end{array}$ & 10 \\
\hline 17 & District office & $\begin{array}{l}\text { District and Head of } \\
\text { subsection }\end{array}$ & 6 \\
\hline 18 & Regent's office & $\begin{array}{l}\text { Head of subsection } \\
\text { and expert staff }\end{array}$ & 4 \\
\hline \multicolumn{3}{|c|}{ Total } & 100 \\
\hline
\end{tabular}

\section{RESULTS AND DISCUSSIONS}

Based on the general model of the cluster of potato agribusiness, it can be translated into a causal loop diagram to understand the complexity of a phenomenon in cluster of potato agribusiness.

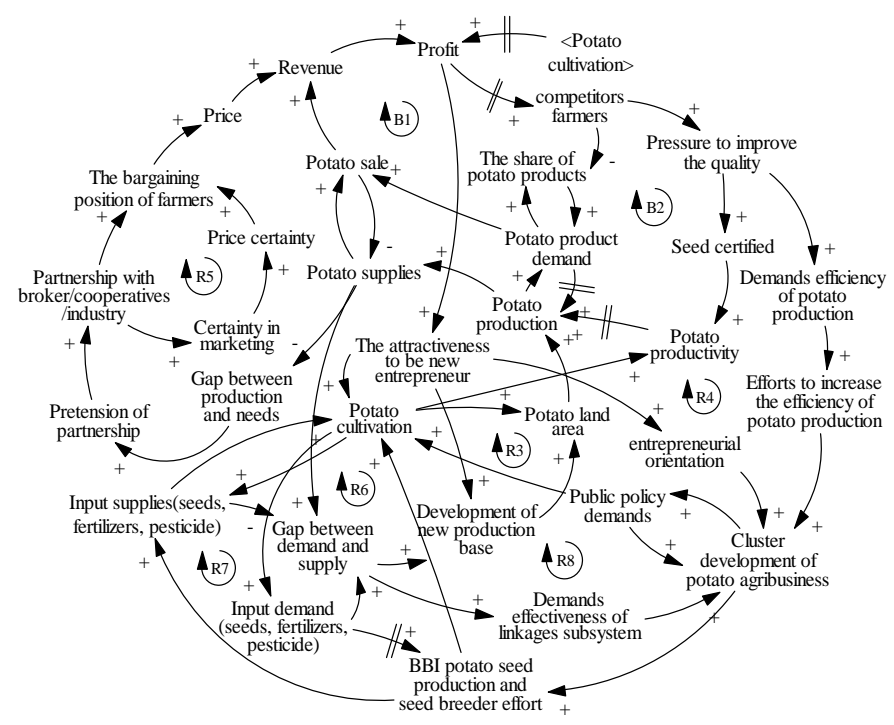

Fig. 2. Causal loop diagram of the cluster of potato agribusiness

Causal loop diagram of the cluster of potato agribusiness is used as the reference of making a diagram flow, by considering the elements those form the entrepreneurial system in the real world, so it can explain the behavior of entrepreneurial model.

\section{A. Entrepreneurial Model}

Entrepreneurship can be classified into two sub-specific models, namely: (1) Sub model of competent farmers of cluster members, and (2) Sub model of the new entrepreneur.

1) Sub model of competent farmers of cluster members: Figure 3, explained that the availability of farmers who are not members of the cluster is a potential determining factor in the increase of farmers. Training and mentoring have effect on the competence of farmers. The number of competent farmers will increase as the training and mentoring process are done better. This will lead to the dynamics of the number of farmers. However, the cluster growth is also limited by the capacity of resources, including human resources which is the main resource in the formation of clusters.

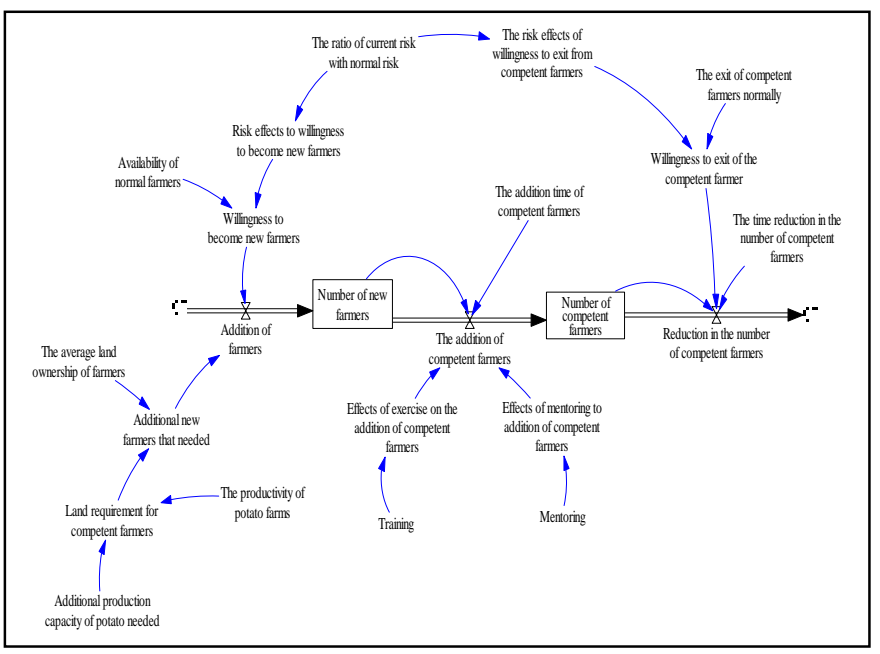

Fig. 3. Sub model of competent farmers of cluster members

2) Sub model of new entrepreneur: Figure 4, explained that the cluster development of agribusiness based on structured market of on-grade potato can increase the income of farmers. Manufacturers also receive income from off-grade potato products that are sold in traditional markets. Accordingly, revenues and profits earned by producers will increase. The increased profitability will rise the interest of new players to become new entrepreneurs in agriculture. With the increasing number of new entrepreneurs to develop potato production base, the production of potato will increase. Thus, the accumulation of production base will increase, as the increasing of production capacity of potato.

The increasing of potato production capacity encourages the increasing of on-grade potato. This condition will rise the accumulation of on-grade potato numbers that makes the sales increased and the income will also rise. The interaction of many variables in creating new entrepreneurs in field of agriculture forms a positive feedback. This indicates that the cluster development of potato agribusiness encourages the 


\section{$\triangle$ ATLANTIS PRESS}

growth of new entrepreneurs so as to increase the interest of farmers/entrepreneurs who are competent in the area of cluster development of potato agribusiness.

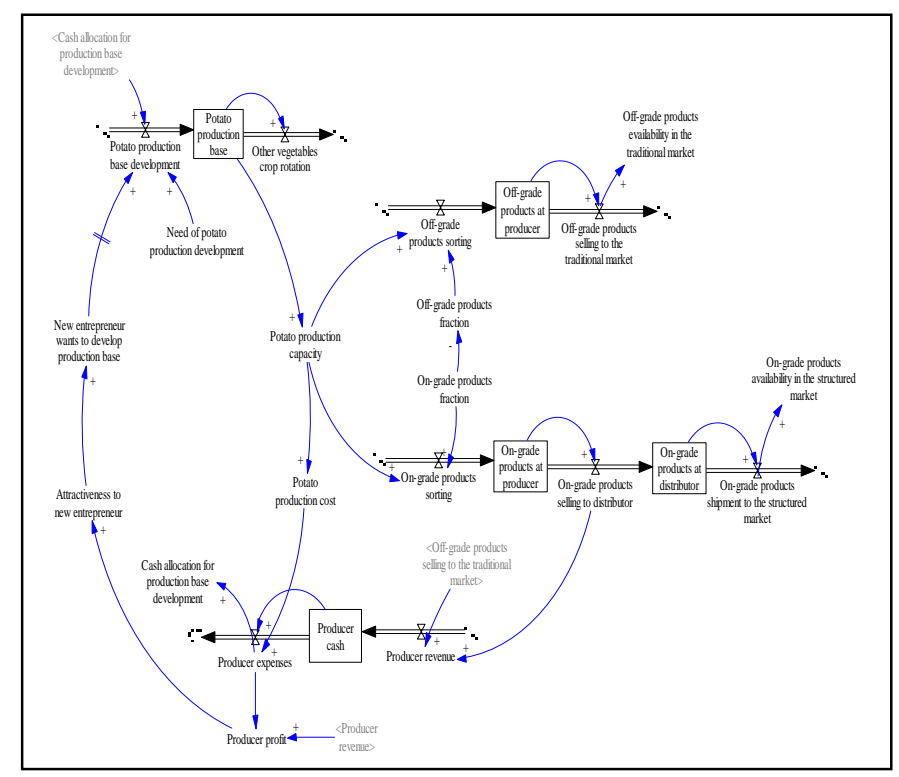

Fig. 4. Diagram of sub model of new entrepreneurs

\section{B. Behavior of Production and Competent Farmers of Potato}

It is estimated that the demand of potato as raw material in the manufacture of potato products will increase by increasing the number of processing industry on large scale and home industry. The increasing demand for potato in line with the number of people who use potato as vegetables daily. The need for potato is also expected to continue to rise despite the public interest in potato consumption is still low, which is around 7 $\mathrm{kg} /$ capita/year, which is consumed by almost the entire population in Indonesia. It will make potato production capacity will be higher and must be supported by the increasing numbers of competent farmers so as to produce potato with high productivity and sustainable.

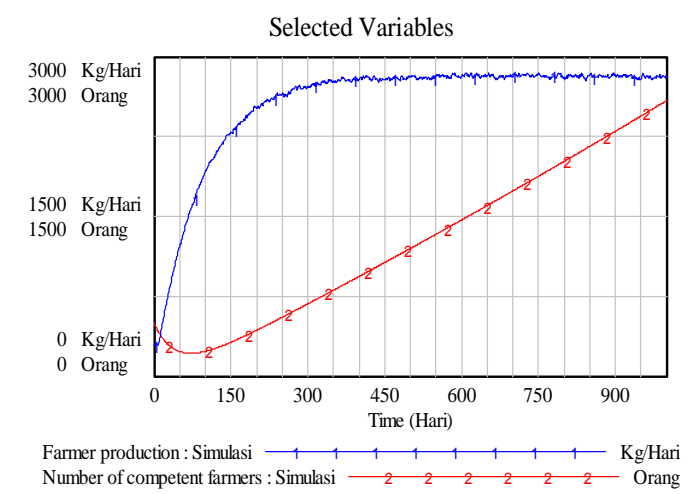

Fig. 5. Behavior of production and competent farmers of potato

The result of modeling and simulation on cluster development of potato agribusiness gives description of the behavior of potato production that is likely to continue to increase with dynamic exhibits behavior. In Figure 5, the simulation result on day 300 , show the number of competent farmers that continue to increase, so potato production continues to increase. This is supported by the increasing in market demand offset by an increase in production. On day 900 , production continues to rise significantly with the increasing number of competent farmers. Most farmers have implemented the use of quality seeds (certified seeds), because of the availability of seed stock in BBI (Parent Seed Center), and supplying seeds at affordable prices by farmers/producers, thus greatly affecting the production of potato farmers.

\section{Behavior of Farmers Advantages and New Entrepreneur}

The results of modeling and simulation on cluster development of potato agribusiness describes the behavior of farmers benefit that tend to increase. As previously explained, that in the last three years, the potato commodity set as the leading commodity in Aceh. Great support from the government of Aceh, with the signing of MoUs export potato to neighboring Malaysia, has increased the motivation of farmers in potato cultivation. Thus, farmers have an opportunity to improve and profit from the export.

Based on Figure 6, it can be seen that the behavior of farmer's benefit continues to increase, influenced by the accretion of market demand, either local, domestic, and export. Market opportunities and the level of promised benefits is influencing the behavior of new entrepreneurs so that the number of new businesses continues to grow. It also affects the stakeholders to facilitate the new entrepreneurs, in order to have access to financial institutions for obtaining venture capital to finance the development of new production base, and the application of technology in the cultivation of potato.

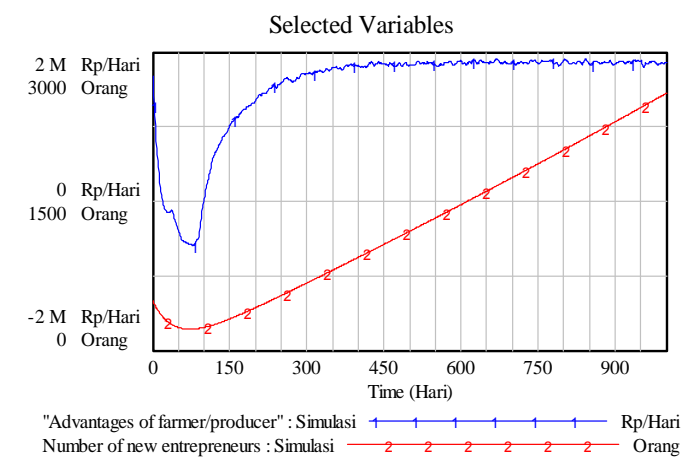

Fig. 6. Behavior of farmers advantages and new entrepreneur

The behavior shown in Figure 6, gives very positive impact in the cluster development of potato agribusiness in Aceh. Hopefully, the interest of new entrepreneurs who invest in the cultivation of potato will continue to increase with increasing profits and revenues received by farmers.

\section{Scenario of Increasing Number of Competent Farmers (new entrepreneurs)}

This scenario is done through an addition of farmers based on actual condition, that is as many as 1,000 people, to be 2,000 to 3,000 farmers/year. Thus, the production and income is expected to continue rising. 


\section{E. Policy Implications Related to Entrepreneurship Against the Cluster Development of Potato Agribusiness}

- Competent human resources are needed in the cluster development of potato agribusiness. Therefore, the government should encourage education and training institutions to incorporate entrepreneurship matter, because the most decisive factor in the success of the cluster development of potato agribusiness is entrepreneurial orientation of the business actors.

- It is necessary to improve the entrepreneurial orientation for prime quality potato product will not be generated without any breakthrough, both on the production line as well as marketing, which can only be done through the development of a proactive attitude, innovative and risk-taking.

- Processing industry needs to develop human resource management based on competency, so that employees who work in the industry has a high level of competence. Human resource development strategy that will be carried out must be integrated with business strategy to be taken, in order to bring success for the industrial company.

- Improvement of the ability to access information is factor that significantly affects entrepreneurial competency for the business clusters. By obtaining more knowledge the farmers will get the ability to analyze problems that makes farmers more willing to take the risk of applying innovation in potato agribusiness by first making a business plan and continues to do an evaluation.

\section{CONCLUSIONS}

The scenario of increasing number of competent farmers in potato cultivation, based on actual condition, that is as many as 1,000 people to be $2,000-3,000$ farmers/year is applied to support the improvement of quality, value added, competitiveness, and bargaining position of farmers in the cluster development of potato agribusiness. It shows that the scenarios give positive impact on increasing the number of potato production.

Market opportunities and the level of promised benefits greatly influence the behavior of new entrepreneurs in investing, so the number of new businesses in the cluster of potato agribusiness grows. It also affects the stakeholders to facilitate the new entrepreneurs, in order to have access to financial institutions for obtaining venture capital, to finance the development of new production base, and the application of technology in potato cultivation.

Model of entrepreneurial orientation in the cluster development of potato agribusiness in Aceh, is a model of human resource management innovation, to accelerate the development of potato commodity, increase revenue and bargaining position of farmers, and be able to drive the regional economy.

The competence of entrepreneurial businesses in the cluster of potato agribusiness can be improved through education and 
training, both technical, and non-technical to actively involve the relevant stakeholders, including Penyuluh Pertanian Lapangan (PPL), Dinas Pertanian Tanaman Pangan dan Hortikultura, and Badan Ketahanan Pangan dan Penyuluh (BKPP), as well as universities, in order to expand the innovation, development of cultivation technology and entrepreneurship, which is needed by entrepreneurs in the cluster of potato agribusiness in Aceh.

Entrepreneurship is not just trading, but it is also related with regard to human mental, confidence, time efficiency, creativity, fortitude, perseverance, sincerity, and morality of doing self business-employment whose purpose is to prepare each individual and community in order to live a decent human being, whose presence is intended to develop themselves, society, nature, and life. The author concludes that entrepreneur is someone who establishes, manages, develops, and institutionalizes its business, and done with a creative, innovative, and forward-looking, able to take advantage of opportunities, is able to get along with, hardworking, confident, and be independent.

\section{ACKNOWLEDGMENT}

This work is financially supported by funded with the help of graduate education (BPPS) of the Directorate General of Higher Education (DIKTI) of the Republic of Indonesia.

\section{REFERENCES}

[1] Direktorat Jendral Hortikultura. Strategi Peningkatan Kualitas dan Kuantitas Hortikultura untuk Ekspor. Makalah Seminar, Kementerian Pertanian, Jakarta 2011.

[2] Dinas Pertanian Tanaman Pangan Aceh. "Biaya Produksi, Produktivitas dan Keuntungan Beberapa Komoditi Tanaman Pangan Per-Ha”. Banda Aceh 2014.

[3] Badan Pusat Statistik Provinsi Aceh. Aceh Dalam Angka 2015. Banda Aceh 2015.

[4] Kasimin, S. "Model Pengembangan Agribisnis Kentang di Provinsi Nanggroe Aceh Darussalam Melalui Analisis Keterkaitan Produk dan Pelaku". Disertasi, Program Pascasarjana Universitas Padjadjaran, Bandung 2009.

[5] Khakbazan, M., Hamilton, C., Moulin, A., Belcher, K., Mohr, R., Volkmar, K., Tomasiewicz, D. Modeling Economic and AgroEnvironmental Dynamics of Potato Production Systems. Journal of Bioecon, 11: 65-93. Springer Science + Business Media, LLC. Canada 2009.

[6] Salwati. Aplikasi Model Simulasi Untuk Prediksi Dampak Perubahan Iklim Terhadap Produktivitas Tanaman Kentang (Solanum tuberosum L.) di Indonesia. Disertasi, Program Studi Klimatologi Terapan, Sekolah Pascasarjana IPB, Bogor 2012.

[7] Martiningrum, FD., Partiwi, SG., Wirjodirdjo, B. Analisis Kinerja Klaster Industri Minyak dan Gas Bumi (MIGAS) di Jawa Timur Dengan Pendekatan Dinamika Sistem. Jurusan Teknik Industri, Institute Teknologi Industri Sepuluh Nopember (ITS), Surabaya 2010.

[8] Wibowo, A. Analisis Pembangunan Klaster Industri Furniture di Kota Palangka Raya. Tesis, Departemen Ilmu Pengetahuan Kehutanan Sekolah Pascasarjana IPB, Bogor 2008.

[9] Chatterji, A., Glaeser, E., Kerr, W. Clusters of Entrepreneurship and Innovation. The Paper of innovation Policy and The Economy Forum, 2013.
[10] Lestari, I., Wirjodirdjo, B. Analisis Kesejahteraan Pelaku Industri Pengolahan Ikan Pada Komunitas Klaster Masyarakat Nelayan Pesisir: Sebuah Pendekatan Dinamika Sistem. Jurusan Teknik Industri, Institut Teknologi Sepuluh Nopember (ITS), Surabaya 2010.

[11] Hendrastuti. Rancang Bangun Model Pemberdayaan Masyarakat Perdesaan Dalam Klaster Agroindustri Minyak Atsiri (Studi Kasus: Minyak Nilam). Disertasi, Program Studi Teknologi Industri Pertanian Sekolah Pascasarjana IPB, Bogor 2012.

[12] Lolowang, TF. Rancang Bangun Model Pengembangan Klaster Agroindustri Aren di Sulawesi Utara. Disertasi, Program Studi Teknologi Industri Pertanian Sekolah Pascasarjana IPB, Bogor 2012.

[13] Suhada, B. Strategi Peningkatan Produktivitas dalam Mendukung Kebijakan Klaster Industri Gula Tebu di Indonesia. Disertasi, Program Studi Teknologi Industri Pertanian, Sekolah Pascasarjana IPB, Bogor 2012 .

[14] Perdana, T., Nurhayati, Kusnandar. Improvement Model of Supply Chain Management and Agribusiness Cluster of Red Chili: an experience in West Java. The Article presented in International Workshop of Agri Supply Chain Management, In Collaboration Between University of Jember and University Putra Malaysia, 2013.

[15] Yu, M., Calzadilla, J., Lopez, JL., Villa, A. 2013. Engineering agro-food development: The cluster model in China. Agricultural Sciences Vol.4, No.9B, 33-39. http://dx.doi.org/10.4236/as.2013.49B006, 2013.

[16] Andayani, SA. Model Kemitraan Klaster Agribisnis Cabai Merah Untuk Mengelola Risiko (Studi Kasus di Kabupaten Garut Jawa Barat). Disertasi, Program Pascasarjana Universitas Padjadjaran, Bandung 2015.

[17] Dharmayanti, I. Desain Model Pengembangan Klaster Industri Hilir Kelapa Sawit di Kawasan Industri Sei Mangkei. Disertasi, Program Studi Teknologi Industri Pertanian, Sekolah Pascasarjana IPB, Bogor 2015 .

[18] Kuratko, DF., and Hodgetts, RM. Entrepreneurship: Theory, Process. Practice (Mason, OH: South-Western Publishers), 2004.

[19] Cantillon. Learning and Human Abilities. Harper \& Row Publiser, New York 1995.

[20] Belodor, M. Sociological Aspect of Agricultural. Harper \& Row Publiser, New York 1991.

[21] Schumpeter, Joseph. "Economic Theory and Entrepreneurial History". In G. Hugh, J. Aitken (Eds), Explorations in Enterprise, Homewood University Press, 1965.

[22] Ronstad, Robert, C. Entrepreneurship, Text, Cases, and Notes. Lord Dover, Massachusetts 1984

[23] Lumpkin, GT., and Dess, GG. Clarifying the Entrepreneurial Orientation Construct and Linking it to Performance. Academy of Management Journal, 21 (1): 135-172, 1996.

[24] Birkinshaw, J. The Paradox of Corporate Entrepreneurship. Strategy and Business, Spring, 2003.

[25] Webster's Ninth New Collegiate Dictionary. http://worldcat.org/title /Websters-ninth-new-collegiate-dictionary/oclc/746901988/editions ?sd=Desc\&se=yr\&referer=di\&qt=facet_yr\%3A\&editionsView=true\&fq $=\mathrm{yr} \% 3 \mathrm{~A} 1991$.

[26] Miller,D. The Correlates of Entrepreneurship in Three Types of Firms. Journal of Management Science, 29 (7): 770-791, 1983.

[27] Covin, JG., and Slevin, DP. The Influence of Organization Structure on the Utility of an Entrepreneurial Top Management Style. Journal of Management Studies, 25(3): 217-259, 1988.

[28] Kimberly, JR. Managerial Innovation in P.C. Nystrom and W.H. Starbuck. Handbook of Organizational Design, Vol. 1. Oxford University Press, New York 1981.

[29] Sterman, JD. Business Dynamics: Systems Thinking and Modeling for a Complex World. Irwin/McGraw-Hill: Boston 2000.

[30] Tasrif, M. Analisis Kebijakan Menggunakan Model System Dynamics. Buku 2: Model Pelatihan Dinamik Sistem, Program Magister Studi Pembangunan SAPPK ITB, Bandung 2004. 